\title{
Noxious gases in rabbit housing systems: effects of cross and longitudinal ventilation
}

\author{
Francesco da Borso, ${ }^{1}$ Alessandro Chiumenti, ${ }^{1}$ Marco Mezzadri, ${ }^{2}$ Francesco Teri ${ }^{2}$ \\ ${ }^{1}$ Department of Agricultural, Food, Environmental and Animal Sciences, University of Udine; \\ ${ }^{2}$ Research collaborator, University of Udine, Italy
}

\begin{abstract}
Animal welfare is a matter of increasing interest due to ethical and economical worries regarding animal rights and the sustainability of meat production. Ammonia, carbon dioxide, and methane can be produced in the livestock buildings and, if not adequately controlled by ventilation, can be dangerous for animals and farmers. The aim of the present paper is to study the effects of different ventilation systems in rabbit buildings based on the temporal patterns and the spatial distribution of these noxious gases. The experimental measurements were conducted in two rabbit farms with genetically homogeneous animals subjected to the same diet. Two buildings with different forced ventilation layouts (cross ventilation - building $A$ and longitudinal ventilation - building B) were subjected to the monitoring of indoor environmental conditions (temperature, relative humidity, ammonia, carbon dioxide, methane) over a whole year. In both the buildings, ventilation was adjusted automatically by means of electronic control units, which
\end{abstract}

Correspondence: Francesco da Borso, Department of Agricultural, Food, Environmental and Animal Sciences (DI4A), University of Udine, via delle Scienze 206, 33100 Udine, Italy.

E-mail: francesco.daborso@uniud.it

Key words: Animal welfare; housing systems; noxious gases; rabbits; ventilation.

Acknowledgements: we are grateful to farmers Cristiano Diotto and Zeno Roma for their useful and kind collaboration. The authors would like to thank Penny Lazo for the professional and kind support for the proof reading and English language editing of the paper.

Funding: the research was funded by the Ministry of Labour, Health and Social Policy, Department of Veterinary Public Health, Nutrition and Food Safety, within the project IZS VE 01/08 RC Evaluation of some environmental parameters in breeding rabbits for meat and correlation with animal welfare, coordinated by Istituto Zooprofilattico delle Venezie, under the scientific responsibility of Dr. Fabrizio Agnoletti.

Received for publication: 15 June 2016 .

Accepted for publication: 7 September 2016.

CC Copyright F. da Borso et al., 2016

Licensee PAGEPress, Italy

Journal of Agricultural Engineering 2016; XLVII:572

doi:10.4081/jae.2016.572

This article is distributed under the terms of the Creative Commons Attribution Noncommercial License (by-nc 4.0) which permits any noncommercial use, distribution, and reproduction in any medium, provided the original author(s) and source are credited. were controlled by temperature sensors, located at the centre of the buildings. Gas concentrations inside the buildings followed clearly defined sinusoidal patterns on a daily basis with the highest values reached in winter during the morning hours for ammonia and during the night hours for carbon dioxide and methane. In particular, ammonia revealed a maximum concentration of $30.7 \mathrm{mg} \mathrm{m}^{-3}$ in building A (cross ventilation) and $12.9 \mathrm{mg} \mathrm{m}^{-3}$ in building B (longitudinal ventilation), whereas the minimum values were 6.0 and $4.2 \mathrm{mg} \mathrm{m}^{-3}$, in building $\mathrm{A}$ and $\mathrm{B}$, respectively. As a consequence, daily mean concentrations of noxious gases, solely could not be considered representative of the actual conditions of air quality in the buildings. The airflow direction clearly influenced the spatial concentration of ammonia, which showed different patterns in the two buildings. In building A, the highest ammonia concentration was in a diffuse central area, whereas in building B, it was determined to be less extended and located in the proximity of the wall equipped with extraction fans. The results of this study provide important indications for the planning and management of housing systems for rabbits including: the correct positioning of gas sensors for regulating ventilation systems must be central in case of cross ventilation, but close to the suction fans in case of longitudinal ventilation; the cross ventilation can lead to ammonia concentration higher than longitudinal ventilation, which is caused by the close and prolonged contact of airflow with manure surface in the channels; fans for longitudinal ventilation must be positioned in the same side of the building where scrapers discharge manure; furthermore, manure scraping has to be performed daily in winter during the hours of the day when ventilation rate is at its maximum.

\section{Introduction}

The high levels of gases into the animal housing environment may affect human and animal health (NIOSH, 2007). Furthermore, the production of ammonia $\left(\mathrm{NH}_{3}\right)$, carbon dioxide $\left(\mathrm{CO}_{2}\right)$, and methane $\left(\mathrm{CH}_{4}\right)$ from intensive farming activities causes serious environmental effects such as global warming, acidification of soils, and eutrophication of waters (Krupa, 2003; Brandt et al., 2011).

Exposure limits for humans at the workplace (threshold limit value - time weighted average, TLV-TWA), defined for working weeks of 40 $\mathrm{h}$ ( 8 working hours per day) are $25 \mathrm{ppm}\left(17.8 \mathrm{mg} \mathrm{m}^{-3}\right)$ for ammonia and $5000 \mathrm{ppm}$ (9000 $\mathrm{mg} \mathrm{m}^{-3}$ ) for carbon dioxide (ACGIH, 2007). However, the exposure of animals to these gases is continuous over time, and often, emissions occur very close to the point of inhalation. Monitoring of indoor air quality in relation to noxious gas concentrations has been extensively conducted during past decades in many animal sectors, including dairy cattle, swine, and poultry and laying hens, as reported by the Commission International du Genie Rural (CIGR) (CIGR, 1994). Most attention was given to $\mathrm{NH}_{3}$, because of the relative high concentration in livestock buildings and because the emissions contribute to severe environmental damage (CIGR, 1994). $\mathrm{NH}_{3}$ produc- 
tion in livestock buildings is considered strongly variable in relation to many farming factors (e.g., feeding, flooring, ventilation) and environmental factors (e.g., air temperature, humidity, wind, and seasonal and diurnal variations) (Calvet et al., 2013). CIGR (1994) reported the following results of $\mathrm{NH}_{3}$ measurements in livestock buildings of different European Countries: 0-18 $\mathrm{mg} \mathrm{m}^{-3}$ from houses for cattle, 1-36 $\mathrm{mg} \mathrm{m}^{-3}$ from pig houses, and up to $36 \mathrm{mg} \mathrm{m}^{-3}$ from houses for laying hens. Concerning the protection of animals kept for farming purposes, legislation in force in the European Union states that gas concentrations must be kept within limits which are not harmful to the animals (European Commission, 1998), but the maximum concentration limits for rabbits are not declared. The Working Group on climatisation of animal houses of CIGR, for all farming animals suggested a maximum concentration of $20 \mathrm{ppm}$ (corresponding to $14.2 \mathrm{mg} \mathrm{m}^{-3}$ ) and $3000 \mathrm{ppm}$ (corresponding to $5.490 \mathrm{~g} \mathrm{~m}^{-3}$ ), respectively for $\mathrm{NH}_{3}$ and $\mathrm{CO}_{2}$ (CIGR, 1994). These same limits are established by European legislation on minimum rules for the protection of chickens kept for meat production (European Commission, 2007), but the methods for gas monitoring in animal housings have not been specified, and there are no standard protocols that set parameters, the positioning of sampling points and the duration of monitoring periods. Many Authors have recently approached these aspects in different livestock buildings with different monitoring methods, but they concentrated more on calculating emission rates from buildings than on detecting indoor gas concentrations (de Sousa et al., 2004; Fabbri et al., 2007; Calvet et al., 2013). Naturally ventilated buildings for dairy cows were monitored by Arcidiacono et al. (2015) and they highlighted large variability of $\mathrm{NH}_{3}$ concentrations in relation to many factors, such as the indoor climate and the airflow, the time of measurement, the different functional areas of the barn, and the cleaning routines.

There is scarce information about air quality and in particular about gas concentrations in rabbit farms (Maertens et al., 2005; Hol et al., 2004). The particular physiology of rabbits and the different housing and manure management systems of rabbit farms do not allow for the use of the equivalent emission factors specific for other animals. Rabbit buildings can adopt various types of ventilation systems (natural ventilation, forced ventilation in negative pressure with transverse layout, longitudinal, or mixed) and ventilation rates can vary largely in dependence of day hours and season (CGIR, 2002). Indeed, there is the probability that peaks in ammonia emission occur during the day (Lefcourt, 2002). For these reasons, environmental conditions of rabbit buildings cannot be effectively described by only considering average values, but should be more properly described by monitoring protocol with detailed measurements in function of time and space. The present paper describes the methodologies of environmental monitoring and the main results obtained by a research carried on for one year in two fattening rabbit farms with diverse forced ventilation layouts (cross and longitudinal). The objectives of this work are to expand the framework of knowledge on these aspects and study the effects of forced ventilation on the daily and spatial variability of $\mathrm{NH}_{3}, \mathrm{CO}_{2}$ and $\mathrm{CH}_{4}$ concentrations.

\section{Materials and methods}

The experimental measurements were performed in two rabbit farms which bred rabbits of the same genetic type, fed with the same diet, during one year and for a total of four fattening cycles (from weaning to adult rabbit). The structures and the ventilation equipment of the two buildings are described accordingly.

\section{Building A}

Building A had a floor area of $560 \mathrm{~m}^{2}$ ( $40 \mathrm{~m}$ long $\times 14 \mathrm{~m}$ wide), eaves height of $2.60 \mathrm{~m}$ and a height of the hipped roof of $3.30 \mathrm{~m}$, for a total volume of $1624 \mathrm{~m}^{3}$ (Table 1). Forced ventilation was cross-sectional: the air inlets were located on the longer side oriented Southeast, whereas extractor fans (in number of 7) were set on the opposite side oriented Northwest. There were five rows of battery cages for a total of 651 does-places, and a maximum capacity of 5700 fattening rabbits. The animals were weaned at the age of 38 days and were slaughtered at 77 days of age, at an average live weight of $2.6 \mathrm{~kg} \mathrm{head}^{-1}$. The specific live weight (l.w.) load corresponded to $26.5 \mathrm{~kg}$ l.w. $\mathrm{m}^{-2}$ and $9.1 \mathrm{~kg}$ l.w. $\mathrm{m}^{-3}$.

\section{Building B}

Building B had a floor area of $513 \mathrm{~m}^{2}$ (57 $\mathrm{m}$ long $\times 9 \mathrm{~m}$ in width), eaves height of $3.50 \mathrm{~m}$, and height of the hipped roof of $4.60 \mathrm{~m}$ for a total volume of $2103 \mathrm{~m}^{3}$ (Table 1). Forced ventilation was longitudinal: four extractor fans were arranged on the North head, whereas the air inlets were located on the median part and on the opposite end of the sidewalls. The battery cages were arranged in three rows for a total of 828 does-places and a maximum capacity of 6500 fattening rabbits. The animals were weaned at the age of 42 days and were slaughtered at 84 days of age at an average live weight of $2.8 \mathrm{~kg} \mathrm{head}^{-1}$. The specific weight load corresponded to $35.5 \mathrm{~kg}$ live weight $\mathrm{m}^{-2}$ and $8.7 \mathrm{~kg} \mathrm{~m}^{-3}$.

In both the buildings, ventilation was adjusted automatically by means of electronic control units, which were controlled by temperature sensors, located at the centre of the buildings. In winter, the minimum air flow was ensured by means of ventilators set at the minimum rotation speed for temperatures below $16^{\circ} \mathrm{C}$. With the increase of indoor temperature, the airflow was regulated, increasing the number of functioning ventilators and their rotation speed by means of electronic inverter systems. Moreover, the side windows were equipped with panels of wetted cellulose to provide evaporative cooling during the summer months. The animal excreta were collected in manure shallow channels below batteries, and their removal was performed daily in the morning at 9:00 a.m. using mechanical scrapers.

\section{Parameters and instruments}

The indoor climate (temperature and relative humidity) was monitored with resistance thermometer sensors (dry and wet bulbs) positioned centrally close to the sensors of the control unit for the ventilation system and were linked to mini-data loggers (Econorma FT-102, Italy) that recorded data every $30 \mathrm{~min}$ (Figure 1). Air speed measurements were implemented in several points of the fan output section with a hot wire anemometer (Babuc M, LSI-Lastem, Italy), and the air-

Table 1. Main technical and productive parameters of the two rabbit housings subjected to environmental monitoring (building $A$, cross-ventilation; building $B$, longitudinal ventilation).

\begin{tabular}{lcc} 
Parameters & Building A & Building B \\
Ventilation layout & Cross & Longitudinal \\
Building length $\times$ width $(\mathrm{m})$ & $40.0 \times 14.0$ & $57.0 \times 9.0$ \\
\hline Initial load of rabbits (number) & 5700 & 6500 \\
Duration of the growing period (days) & 38 & 42 \\
\hline Slaughtering weight $\left(\mathrm{kg} \mathrm{head}^{-1}\right)$ & 2.6 & 2.8 \\
Specific l.w. load on surface $\left(\mathrm{kg} \mathrm{m}^{-2}\right)$ & 26.5 & 35.5 \\
\hline Specific l.w. load on volume $\left(\mathrm{kg} \mathrm{m}^{-3}\right)$ & 9.1 & 8.7 \\
\hline
\end{tabular}

I.w., live weight. 
flow was calculated as the product of the average air speed and the outlet area. The total airflow applied in each building was assessed taking into account the number, the working time, and the rotation speed of fans. The concentration of gases $\left(\mathrm{NH}_{3}, \mathrm{CO}_{2}\right.$, and $\left.\mathrm{CH}_{4}\right)$ was measured with two multi-gas analysers (Brüel\&Kjær 1302, Denmark) based on infrared-photoacoustic spectroscopy.

\section{Monitoring protocols and sampling points}

The experimental activity in the two farms continued for a whole year in order to cover a full fattening cycle for each season of the year. The monitoring of gases was done during one week after weaning and one week before slaughter, aiming to determine the temporal and spatial variability of the concentrations of gases, as described hereinafter. The temporal variability was determined with the automatic and continuous monitoring during each week, establishing a sampling rate equal to 30 min by placing the sampling point in a central location of the buildings in contact with the upper part of the cages in the vicinity of the animals (Figure 1). The spatial variability was determined only for $\mathrm{NH}_{3}$ every last day of each monitoring period, when the load of live weight was at maximum level; therefore, the most critical environmental conditions were to be expected. The air sampling was performed manually by displacing the monitor sampling tubes at predetermined points along the rows of the batteries (in 13 points for building $\mathrm{A}$, in 11 points for building B, Figure 1) and retrieving the air from the vicinity of the cages. In each survey point, samples were subjected to examination at intervals of 2 min, using 5 stable measurements to calculate the representative mean for each sampling point.

\section{Data analysis}

To compare the excursions of measured values in the two farms, in the four seasons, and in different points of measurements, the following Equation was used (1):

$$
\mathrm{X}_{h, p}=\frac{C_{h, p}}{\mu}-1
$$

where $C_{h, p}$ is the value at hour $h$ or in the point $p, \mu$ is the average concentration of that gas (on time or space basis). In this way, for all the measurements, the values $X_{\mathrm{h}, \mathrm{p}}$ fluctuated more or less widely, with positive or negative sign around 0 . The daily variation rhythm of the gas concentration was modelled using the following Equation (2), derived from the Fourier transformed series proposed by Calvet et al. (2011):

$$
\mathrm{X}_{h}=-A \cos \left(\frac{\pi}{12} t_{i}-\frac{\pi}{12} t_{\min }\right)
$$

where $A$ is the modelled amplitude of the data $\mathrm{X}_{\mathrm{h}}, t_{i}$ is time $(\mathrm{h}), \mathrm{t}_{\min }$ is the time at which the minimum value is achieved $(\mathrm{h})$ in the span of the period of $24 \mathrm{~h}$. For each data set $\mathrm{X}_{\mathrm{h}}$, the terms $A$ and $\mathrm{t}_{\min }$ of the Equation (2) and the related coefficients of determination $\mathrm{R}^{2}$ were calculated with SEMoLa 6.4.5 modelling framework (Danuso and Rocca, 2012). The performance of the spatial distribution for the gas concentration has been described in graphical form, by processing the data with the software Surfer 8.0 (Golden Inc., 2002), using the minimum curvature gridding method and producing their related iso-concentration maps.

\section{Results and discussion}

\section{Environmental conditions}

The daily average indoor temperature in the monitoring periods ranged from the lowest value of $12.5^{\circ} \mathrm{C}$, recorded in winter in building $\mathrm{B}$, to the highest value $25.6^{\circ} \mathrm{C}$ in summer in building $\mathrm{A}$ (Table 2). The daily average relative humidity ranged from the lowest value of $55.0 \%$ in spring, to the highest value of $71.2 \%$ in winter, both in building B. Passing from winter to summer, the specific flow rate of ventilation increased from 0.75 to $3.15 \mathrm{~m}^{3} \mathrm{~h}^{-1} \mathrm{~kg}^{-1}$ of l.w. in building $\mathrm{A}$, and from 0.30 to $5.4 \mathrm{~m}^{3} \mathrm{~h}^{-1} \mathrm{~kg}^{-1}$ of l.w. in building $\mathrm{B}$.

\section{Gas concentration}

Average gas concentrations measured in the central part of the buildings was determined to be higher in winter and autumn (Table 2). The maximum level of $14.2 \mathrm{mg} \mathrm{m}^{-3}(20 \mathrm{ppm})$ recommended by CIGR (1994) was surpassed only in building A (30.7 and $15.2 \mathrm{mg} \mathrm{m}^{-3}$, in winter and in autumn, respectively). The higher $\mathrm{NH}_{3}$ concentrations measured in building A could be explained by various hypotheses: i) a higher production of $\mathrm{NH}_{3}$, as a consequence of higher air temperatures and a relatively higher animal load; ii) a higher volatilisation with cross ventilation, since airflow is forced to pass beneath the cages in continued contact with manure channels. Instead, with longitudinal ventilation, the air tends to flow along the corridors between the cages; iii) incidental suction of air from the output slots of the manure channels, which communicate with external storage tank; in building B with the longitudinal ventilation, the outlet of the channels is just beneath the fans, so there is the immediate evacuation of the exhausted air.

Table 2. Indoor climatic conditions, airflow rates, and gas concentrations in the two rabbit houses (building A, cross - ventilation; building B, longitudinal ventilation). Mean values \pm standard deviation of each parameter are reported, during the monitoring week

\begin{tabular}{|c|c|c|c|c|c|c|c|}
\hline & Building & $\begin{array}{l}\text { Temperature } \\
\left({ }^{\circ} \mathrm{C}\right)\end{array}$ & $\begin{array}{l}\text { Relative humidity } \\
(\%)\end{array}$ & $\begin{array}{c}\text { Airflow rate } \\
\left(\mathrm{m}^{3} \mathrm{~h}^{-1} \mathrm{~kg}^{-1} \text { l.w. }\right)\end{array}$ & $\begin{array}{c}\mathrm{NH}_{3} \\
\left(\mathrm{mg} \mathrm{m}^{-3}\right)\end{array}$ & $\begin{array}{c}\mathrm{CO}_{2} \\
\left(\mathrm{~g} \mathrm{~m}^{-3}\right)\end{array}$ & $\begin{array}{c}\mathrm{CH}_{4} \\
\left(\mathrm{mg} \mathrm{m}^{-3}\right)\end{array}$ \\
\hline Winter & $\begin{array}{l}\text { A } \\
\text { B }\end{array}$ & $\begin{array}{l}16.3 \pm 1.2 \\
12.5 \pm 0.5\end{array}$ & $\begin{array}{l}71.0 \pm 5.1 \\
71.2 \pm 0.3\end{array}$ & $\begin{array}{l}0.75 \pm 0.05 \\
0.30 \pm 0.02\end{array}$ & $\begin{array}{l}30.7 \pm 4.1 \\
12.9 \pm 1.3\end{array}$ & $\begin{array}{l}3.1 \pm 0.4 \\
3.0 \pm 0.5\end{array}$ & $\begin{array}{l}8.1 \pm 2.1 \\
3.7 \pm 1.1\end{array}$ \\
\hline Spring & $\begin{array}{l}\text { A } \\
\text { B }\end{array}$ & $\begin{array}{l}19.0 \pm 3.1 \\
18.2 \pm 2.3\end{array}$ & $\begin{array}{l}55.8 \pm 0.1 \\
55.0 \pm 1.3\end{array}$ & $\begin{array}{c}1.35 \pm 0.15 \\
2.4 \pm 0.20\end{array}$ & $\begin{array}{l}6.8 \pm 1.4 \\
5.6 \pm 1.5\end{array}$ & $\begin{array}{l}1.4 \pm 0.3 \\
1.2 \pm 0.2\end{array}$ & $\begin{array}{l}2.5 \pm 0.7 \\
3.8 \pm 0.8\end{array}$ \\
\hline Summer & $\begin{array}{l}\text { A } \\
\text { B }\end{array}$ & $\begin{array}{l}25.6 \pm 1.7 \\
24.8 \pm 2.2\end{array}$ & $\begin{array}{l}59.7 \pm 4.7 \\
67.7 \pm 1.8\end{array}$ & $\begin{array}{l}3.15 \pm 0.25 \\
5.40 \pm 0.60\end{array}$ & $\begin{array}{l}6.0 \pm 1.7 \\
4.2 \pm 1.7\end{array}$ & $\begin{array}{l}1.6 \pm 0.4 \\
1.3 \pm 0.3\end{array}$ & $\begin{array}{l}5.8 \pm 2.3 \\
6.3 \pm 1.4\end{array}$ \\
\hline Autumn & $\begin{array}{l}\text { A } \\
\text { B }\end{array}$ & $\begin{array}{l}18.8 \pm 0.8 \\
17.5 \pm 3.4\end{array}$ & $\begin{array}{l}68.4 \pm 3.4 \\
58.5 \pm 7.9\end{array}$ & $\begin{array}{c}0.95 \pm 0.25 \\
1.6 \pm 0.60\end{array}$ & $\begin{array}{c}15.2 \pm 3.5 \\
8.5 \pm 1.4\end{array}$ & $\begin{array}{l}2.8 \pm 0.4 \\
1.8 \pm 0.2\end{array}$ & $\begin{array}{l}8.2 \pm 2.0 \\
0.6 \pm 0.3\end{array}$ \\
\hline
\end{tabular}
in the four seasons.

l.w., live weight. 
The highest levels of $\mathrm{CO}_{2}$ were measured in winter ( 3.1 and $3.0 \mathrm{~g} \mathrm{~m}^{-3}$, in building $\mathrm{A}$ and $\mathrm{B}$, respectively), but during all the monitoring period they were lower than the maximum recommended by the CIGR ( $5.5 \mathrm{~g}$ $\mathrm{m}^{-3}$, equal to $3000 \mathrm{ppm}$ ). Research carried out by other authors (Calvet et al., 2011; Estellés et al., 2011) reported maximum concentrations of $\mathrm{NH}_{3}$ up to $14.3 \mathrm{mg} \mathrm{m}^{-3}$, only slightly above the maximum threshold recommended by CIGR, and maximum concentrations of $\mathrm{CO}_{2}$ up to $7.0 \mathrm{~g}$ $\mathrm{m}^{-3}$ recorded in winter.

The concentrations of $\mathrm{CH}_{4}$ in different seasons ranged from $0.6 \mathrm{mg}$ $\mathrm{m}^{-3}$ to $8.2 \mathrm{mg} \mathrm{m}^{-3}(0.9-12.3 \mathrm{ppm})$, with the highest concentrations found in autumn (building A) and in summer (building B) (Table 2).
Data on concentrations of methane in the intensive farming of rabbits are very scarce in the literature. Calvet et al. (2011) determined average methane concentrations below $6.7 \mathrm{mg} \mathrm{m}^{-3}(10 \mathrm{ppm})$.

\section{Variations of gas concentration in time and space}

Indoor gas concentrations showed daily sinusoidal patterns, following regression Equation (2) with different accuracy degrees. Reported in Table 3 are coefficients of determination $\left(R^{2}\right)$ and values of the amplitude (A) and of the time at which the minimum values were reached $\left(\mathrm{t}_{\min }\right)$. Illustrated in the graphs of Figures 2-5 are the trends of

Table 3. Coefficient of determination $\left(R^{2}\right)$ and terms (A, amplitude; $t_{\min }$, time at which the minimum value of concentration is reached) of the modelled equation for the description of daily variations of gas concentration in two rabbit housings (building $\mathrm{A}$, cross-ventilation; building $B$, longitudinal ventilation).

\begin{tabular}{|c|c|c|c|c|c|c|c|}
\hline \multirow{2}{*}{ Season } & \multirow[b]{2}{*}{ Gas } & \multicolumn{3}{|c|}{ Building A } & \multicolumn{3}{|c|}{ Building B } \\
\hline & & $\mathbf{R}^{2}$ & A & $\mathrm{t}_{\min }(\mathrm{h})$ & $\mathbf{R}^{2}$ & A & $t_{\min }(h)$ \\
\hline \multirow[t]{3}{*}{ Winter } & $\mathrm{NH}_{3}$ & 0.758 & 0.16 & 23:00 & 0.918 & 0.13 & 21:30 \\
\hline & $\mathrm{CO}_{2}$ & 0.857 & 0.17 & $14: 24$ & 0.513 & 0.15 & 13:00 \\
\hline & $\mathrm{CH}_{4}$ & 0.889 & 0.34 & $14: 00$ & 0.716 & 0.35 & $12: 54$ \\
\hline \multirow[t]{3}{*}{ Spring } & $\mathrm{NH}_{3}$ & 0.799 & 0.25 & $17: 12$ & 0.761 & 0.34 & 15:42 \\
\hline & $\mathrm{CO}_{2}$ & 0.898 & 0.26 & $15: 54$ & 0.731 & 0.15 & $14: 30$ \\
\hline & $\mathrm{CH}_{4}$ & 0.856 & 0.38 & $14: 30$ & 0.339 & 0.16 & $12: 54$ \\
\hline \multirow[t]{3}{*}{ Summer } & $\mathrm{NH}_{3}$ & 0.666 & 0.32 & $19: 24$ & 0.922 & 0.55 & 16:06 \\
\hline & $\mathrm{CO}_{2}$ & 0.855 & 0.32 & $15: 12$ & 0.952 & 0.29 & 15:06 \\
\hline & $\mathrm{CH}_{4}$ & 0.737 & 0.48 & $14: 42$ & 0.959 & 0.30 & $13: 48$ \\
\hline \multirow[t]{3}{*}{ Autumn } & $\mathrm{NH}_{3}$ & 0.733 & 0.27 & 18:54 & 0.810 & 0.20 & 18:36 \\
\hline & $\mathrm{CO}_{2}$ & 0.606 & 0.16 & 15:06 & 0.770 & 0.16 & $16: 18$ \\
\hline & $\mathrm{CH}_{4}$ & 0.700 & 0.28 & $14: 48$ & 0.069 & 0.16 & $17: 18$ \\
\hline
\end{tabular}
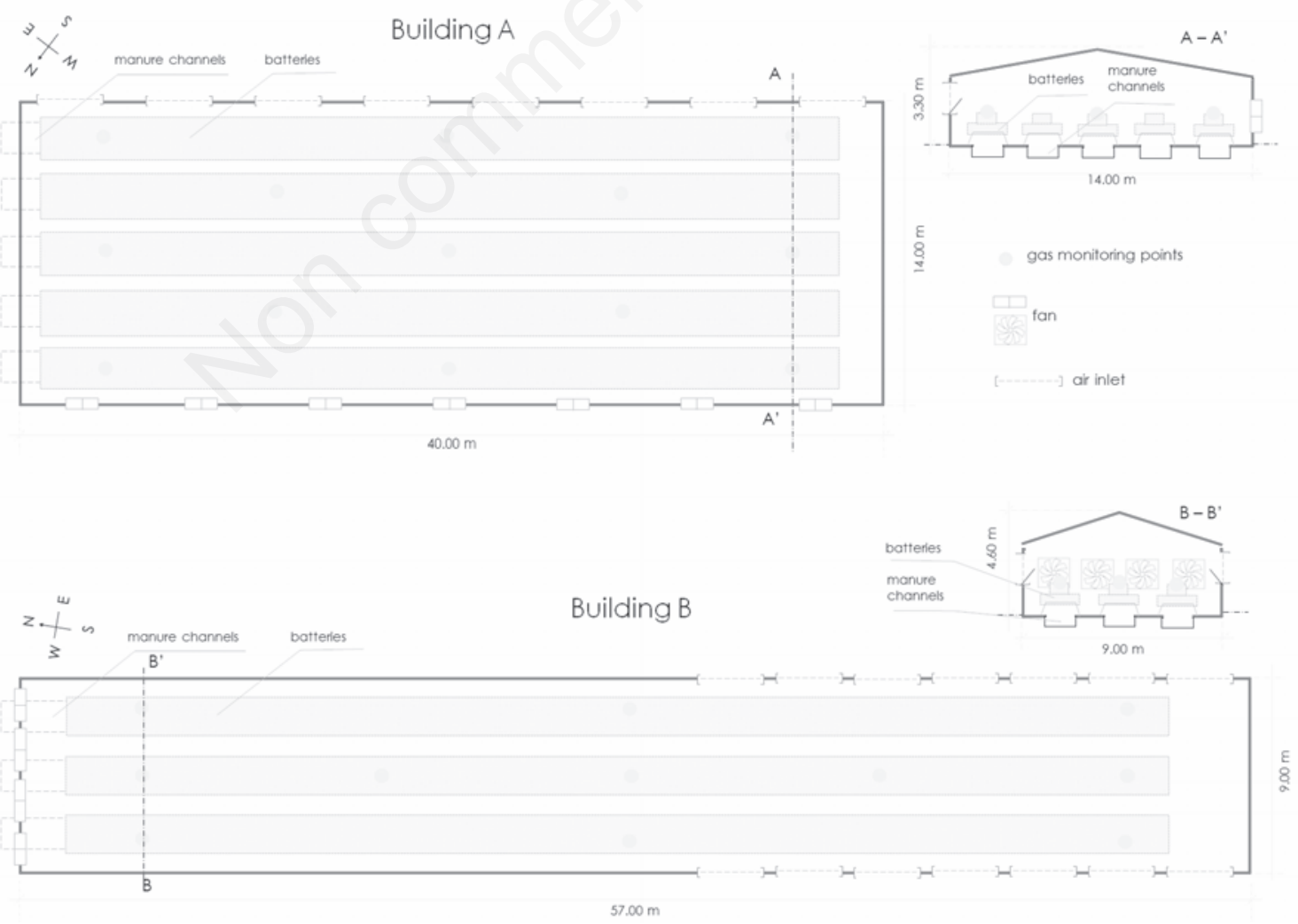

Figure 1. Schemes of the two rabbit buildings (building A, cross-ventilation; building B, longitudinal ventilation), with location of air inlets, fans, the measuring points for climatic parameters, and gas concentrations. 
the modelled equations for the gases in the two buildings, both in winter and summer conditions. Daily excursions of gases were larger in the summer, and the values of amplitude of $\mathrm{NH}_{3}$ were highest, respectively 0.32 and 0.55 in building A and B. Estellés et al. (2010a, 2010b) discovered amplitude for $\mathrm{CO}_{2}$ of $\pm 16.1 \%$ and $t_{\min }$ at $02: 54$ p.m., which seems to coincide quite well with the equations modelled in these two buildings for autumn and winter. Daily concentration patterns of $\mathrm{CO}_{2}$ and $\mathrm{CH}_{4}$ were similar to each other during winter and summer, with $\mathrm{t}_{\mathrm{min}}$ that occurred in daylight hours, between the 12:54 a.m. and 03:12 p.m.
$\mathrm{NH}_{3}$ concentrations showed patterns shifted with respect to other gases, with $t_{\min }$ in summer reached in the afternoon, at 04:06 p.m. (building B) and at 07:24 p.m. (building A), and in winter in the evening hours 09:30 p.m. (building B) and 11:00 p.m. (building A). In winter, the maximum concentrations of $\mathrm{NH}_{3}$ were reached in daylight hours between the hours of 09:00 a.m. and 11:00 a.m.. Similar patterns in the trend of the concentration of $\mathrm{NH}_{3}$ were described by Calvet et al. (2011). The increase in the concentration of $\mathrm{NH}_{3}$ during the morning hours may have been caused by the operations of removal of manure in

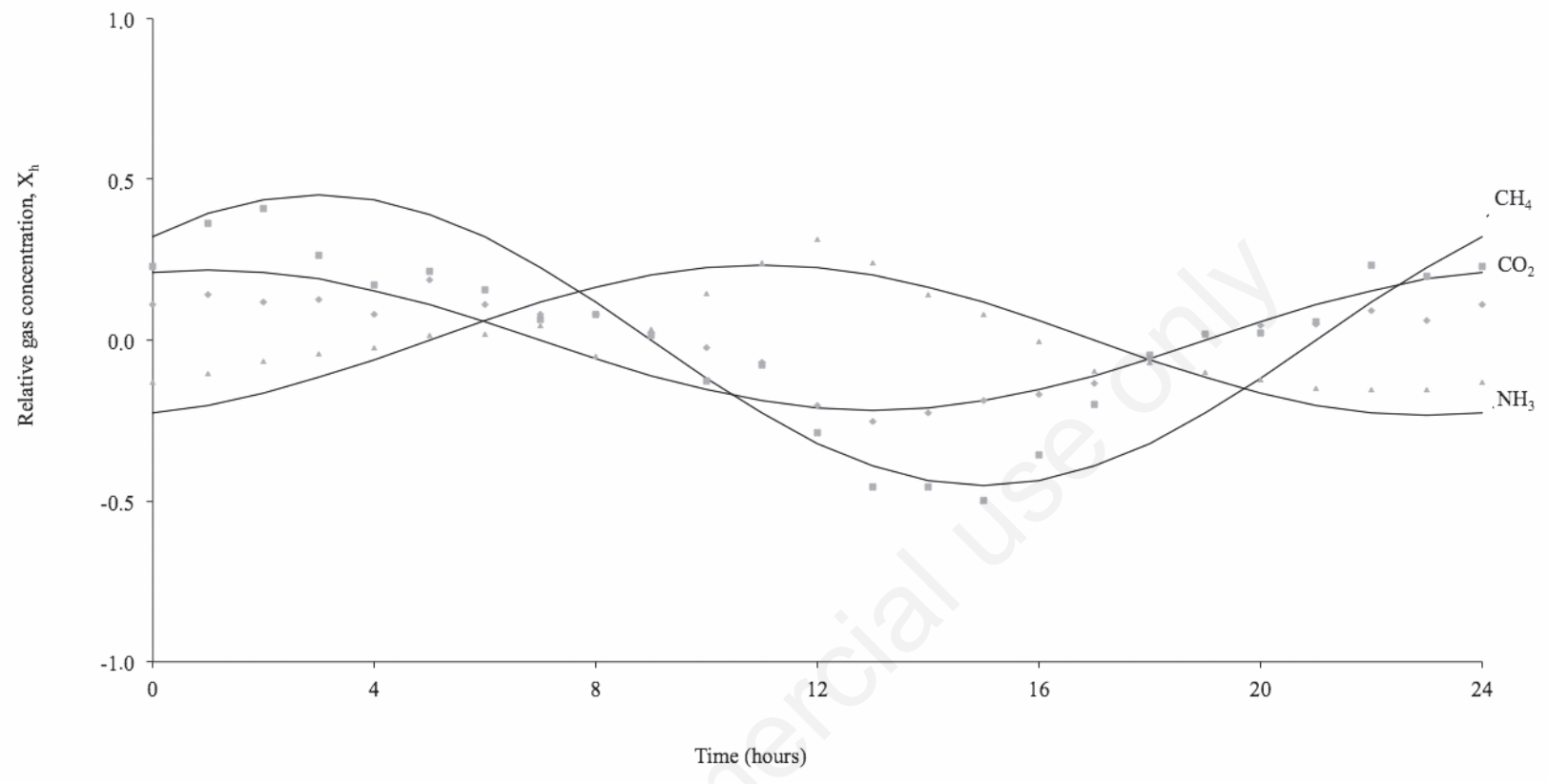

Figure 2. Daily patterns of relative gas concentration $\left(\mathrm{X}_{\mathrm{h}}\right)$ in winter in rabbit building A with cross-ventilation. Symbols refer to hourly measured concentrations of different gases; full lines describe the modelled patterns.

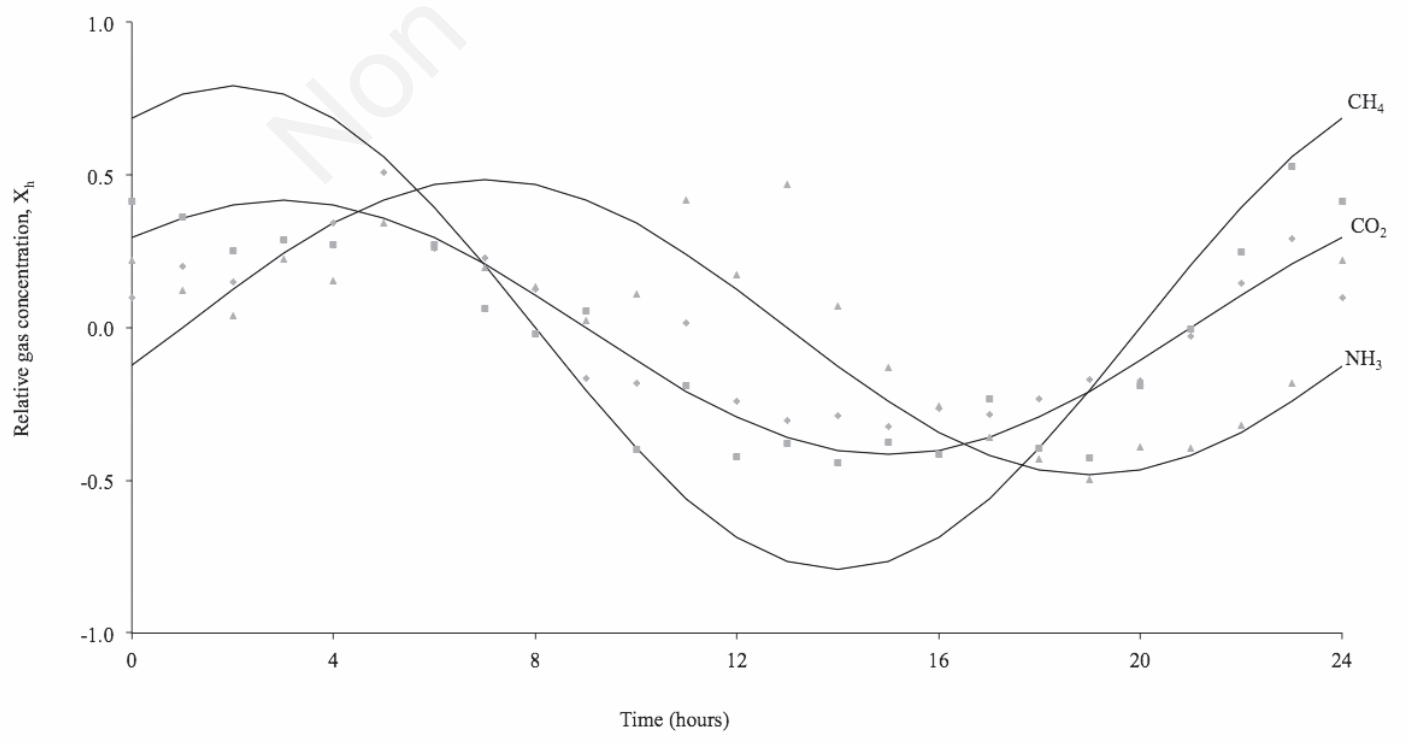

Figure 3. Daily patterns of relative gas concentration $\left(X_{h}\right)$ in summer in rabbit building $A$ with cross-ventilation. Symbols refer to hourly measured concentrations of different gases; full lines describe the modelled patterns. 
the two farms, which occurred between 08:00 a.m. and 09:00 a.m. The scrapers were operating effectively for removal of solid manure, but the bottom of the channels remained wet of urine, which was identified as the main cause of emissions of $\mathrm{NH}_{3}$ (Groot Koerkamp et al., 1998). The concentration of ammonia in livestock buildings has been distributed with evident spatial gradients dependent on season and building. Reported in the graphs of Figures 6 and 7 are the gradients in winter, when the highest concentrations of $\mathrm{NH}_{3}$ were reached. The graphs demonstrate the values $X_{p}$, expressed by the transformation of
Equation (1), and the areas with higher concentrations with respect to the mean are enclosed by the curves denoted by positive values. In both the buildings, the measured $\mathrm{NH}_{3}$ concentrations followed the pattern theoretically expected on the basis of airflow direction, with the lowest concentration near the air inlet and the highest near the outlet; however, some unexpected behaviours were found. In fact, in building A, the highest $\mathrm{NH}_{3}$ concentrations were found in an extended area from the central part of the building, shifted toward the longitudinal wall equipped with the fans and slightly toward the wall with manure chan-

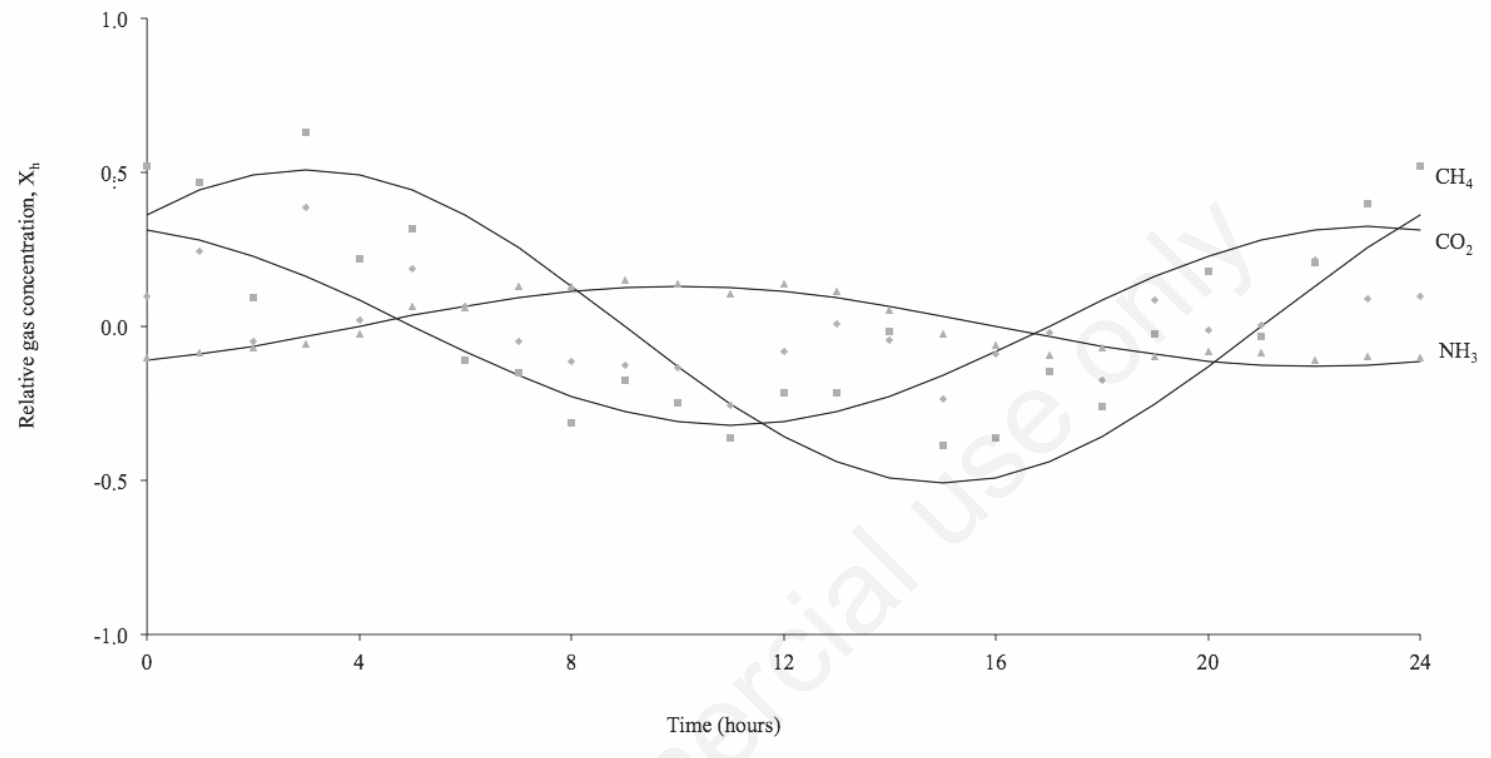

Figure 4. Daily patterns of relative gas concentration $\left(X_{h}\right)$ in winter in rabbit building B with longitudinal ventilation. Symbols refer to hourly measured concentrations of different gases; full lines describe the modelled patterns.

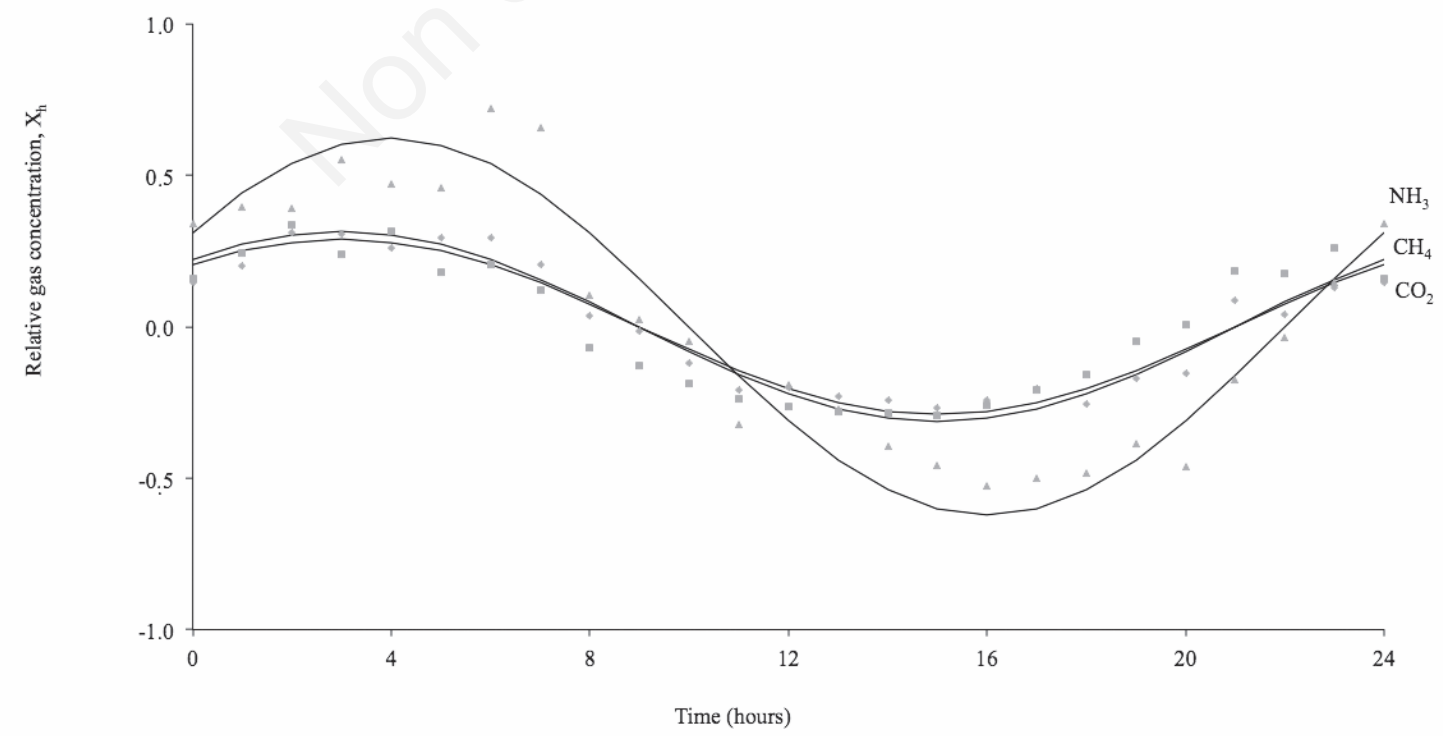

Figure 5. Daily patterns of relative gas concentration $\left(X_{h}\right)$ in summer in rabbit building $B$ with longitudinal ventilation. Symbols refer to hourly measured concentrations of different gases; full lines describe the modelled patterns. 
nels outlet. In building B, the highest concentrations were reached in a well-defined area toward the fans, but in the major part of building asymmetry of $\mathrm{NH}_{3}$ concentrations was observed between East side and West side of the walls. Several hypotheses could explain these phenomena: i) influence of pressure due to the wind from outdoor, in relation to the presence of obstacles near the windows (trees, other equipment, and buildings). This could be the case of building $B$ where a similar building was located a few meters from West wall; ii) incoming air from other incidental openings of the buildings (doors, outlet of the manure channels, as discussed above, shutting of the fans not perfectly airtight).

\section{Conclusions}

The quality of the indoor environment of rabbit buildings is controlled by the ventilation systems and is not assessable solely by the daily mean concentration of gases in the buildings. The present study demonstrated that indoor gas concentrations followed a sinusoidal pattern on a daily basis, with the most critical periods for $\mathrm{NH}_{3}$ during the morning hours. This behaviour was similar both in cross-ventilated and longitudinally ventilated buildings, which was mostly related to the manure scraping operations. For reducing the peaks in $\mathrm{NH}_{3}$ concentration, it might be useful to perform removal of manure during the central hours of the day, when airflow rate is at maximum value. Ventilation layouts influenced spatial distribution of internal $\mathrm{NH}_{3}$ concentrations. The highest $\mathrm{NH}_{3}$ concentrations were found in an extended area of the central part of the building with cross-ventilation and in a more limited area of the building towards the walls of the fans with longitudinal ventilation. These behaviours were only partially determined by the expected accumulation of $\mathrm{NH}_{3}$ along the airflow trajectory from the inlet to the outlet. Other phenomena might have influenced the different gas patterns in the two ventilation systems which include: the more prolonged contact of airflow with manure in the building with cross ventilation; the suction of air from incidental openings (i.e., from the outlets of manure channels in the building with cross ventilation); the variable pressure of the wind from outside the building, which might influence differences in air incoming from the two longitudinal walls in the building with longitudinal ventilation. The automatic control of forced ventilation on the basis of the internal air temperature only, as normally applied in rabbit buildings, could not adequately ensure favourable air quality. It could be useful to adopt the automatic control of ventilation by using gas detection sensors. In this regard, the

Continuous openings for air inlet

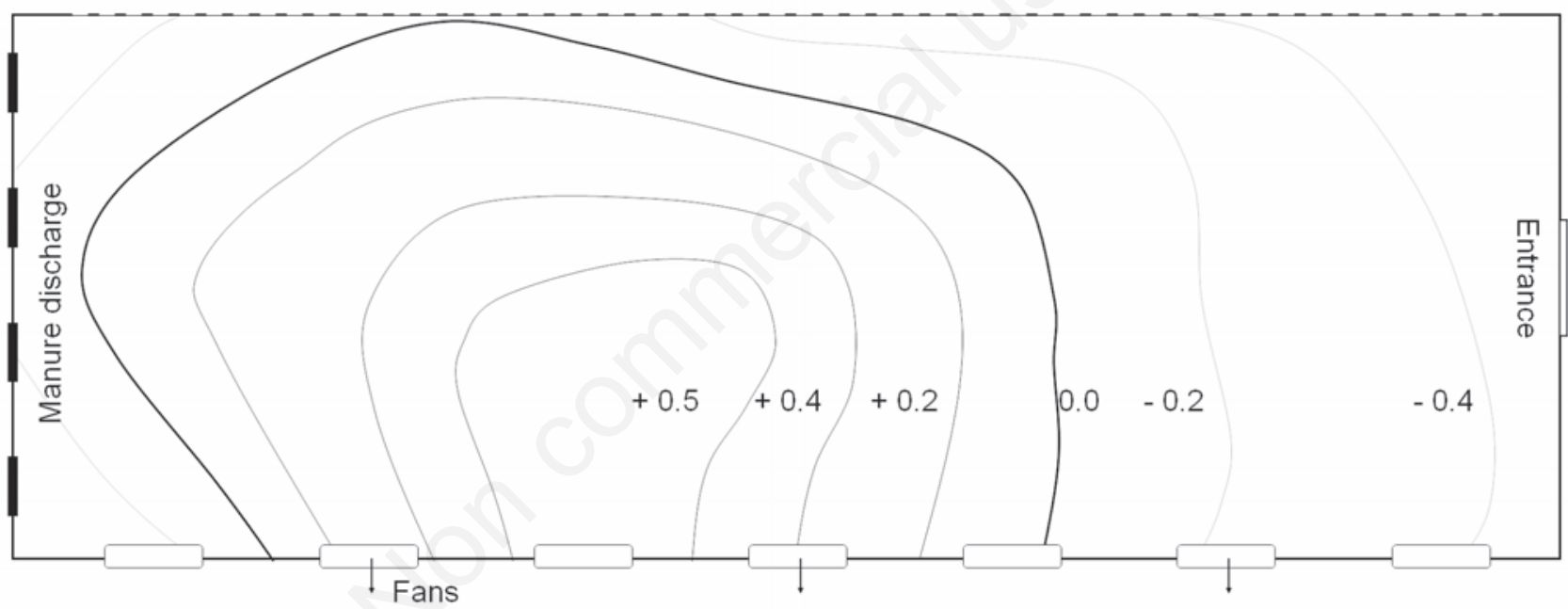

Figure 6. Spatial patterns of relative ammonia concentration $\left(X_{p}\right)$ in rabbit building A with cross - ventilation, in winter. Positions of air inlets, fans, and manure discharges are indicated.

Continuous openings for air inlet

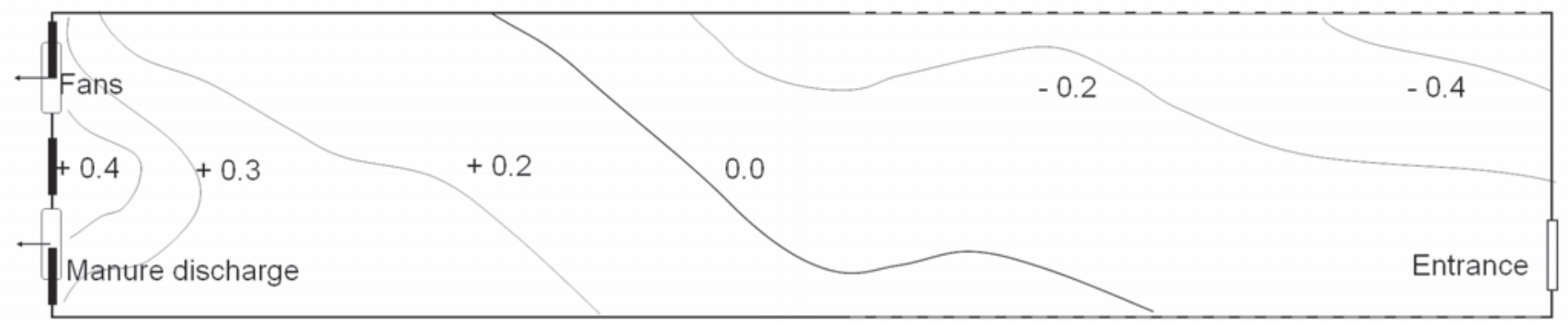

Figure 7. Spatial patterns of relative ammonia concentration $\left(\mathrm{X}_{\mathrm{p}}\right)$ in rabbit building $\mathrm{B}$ with longitudinal ventilation, in winter. Positions of air inlets, fans, and manure discharges are indicated. 
present study has prompted the conclusion that $\mathrm{CO}_{2}$ monitoring (for which there are reliable sensors with relatively low cost) is not sufficient, and it is necessary to provide $\mathrm{NH}_{3}$ monitoring (however, for which reliable sensors are more expensive). In order to avoid critical conditions, the displacement of gas sensors should be at the top of the cages in a central position with cross-ventilation and adjacent to the fans with longitudinal ventilation.

\section{References}

ACGIH (American Conference of Governmental Industrial Hygienists). 2007. Threshold limits values for chemical substances and physical agents. Biological Exposure Indices (BEIs), Cincinnati, OH, USA.

Arcidiacono C., Porto S.M.C., Cascone G. 2015. On ammonia concentrations in breeding environments of dairy houses located in the Iblean Highlands. Agric. Engine. Int. CIGR J. Special Issue 2015:294-305.

Brandt J., Silver J.D., Christensen J.H., Andersen M.S., Bønløkke J., Sigsgaard T., Geels C., Gross A., Hansen A.B., Hansen K.M., Hedegaard G.B., Kaas E., Frohn L.M. 2011. Assessment of healthcost externalities of air pollution at the national level using the EVA model system. CEEH Scientific Report No. 3. Available from: www.ceeh.dk

Calvet S., Cambra-López M., Estellés Barber F., Torres A.G. 2011. Characterization of the indoor environment and gas emissions in rabbit farms. World Rabbit Sci. 19:49-61.

Calvet S., Gates R.S., Zhang G., Estellés F., Ogink N.W.M., Pedersen S., Berckmans D. 2013. Measuring gas emissions from livestock buildings: a review on uncertainty analysis and error sources. Biosyst Eng. 116:221-31.

CIGR (International Commission of Agricultural Engineering). 1994. Aerial environment in animal houses: concentrations in and emissions from farm buildings. Working Group Report Series No. 94.1. CEMAGREF Editions, Rennes Cedex, France. Available from: http://www.cigr.org Accessed: May 2016.

CIGR (International Commission of Agricultural and Biosystems Engineering). 2002. Climatization of animal houses. Heat and moisture production at animal and house level. In: S. Pedersen and K. Sällvik (Ed.), $4^{\text {th }}$ Report of CIGR Working Group, Research Centre Bygholm, Danish Institute of Agricultural Sciences, Denmark, pp 1-46.

Danuso F., Rocca A. 2012. SEMoLa simple and easy modelling language, ver. 6.4.5. Available from: http:/www.dpvta.uniud.it/ Danuso/docs/ Semola/homep.htm Accessed: May 2016.

de Sousa P., Pedersen S. 2004. Ammonia emission from fattening pig houses in relation to animal activity and carbon dioxide production. Agric. Engine. Int. CIGR J. Sci. Res. Develop. VI:BC04-003.

Estellés F., Calvet S., Ogink N.W.M. 2010a. Effects of diurnal emission patterns and sampling frequency on precision of measurement methods for daily ammonia emissions from animal houses. Biosyst Eng. 107:16-24.

Estellés F., Fernandez N., Torres A.G., Calvet S. 2011. Use of $\mathrm{CO}_{2}$ balances to determine ventilation rates in a fattening rabbit house. Span. J. Agric. Res. 9:713-20.

Estellés F., Rodríguez-Latorre A.R., Calvet S., Villagrá A., Torres A.G. 2010b. Daily carbon dioxide emission and activity of rabbits during the fattening period. Biosyst. Eng. 106:338-43.

European Commission. 1998. Directive 98/58/EC of the European parliament and of the Council on the protection on animal kept for farming purposes. In: Official Journal, L 221, 08/08/1998, pp 23-27.

European Commission. 2007. Directive 2007/43/EC of the European parliament and of the Council on laying down minimum rules for the protection of chickens kept for meat production. In: Official Journal, L 12/07/2007, pp 19-28.

Fabbri C., Valli L, Guarino M, Costa A, Mazzotta V. 2007. Ammonia, methane, nitrous oxide and particulate matter emissions from two different buildings for laying hens. Biosyst. Engine. 97:441-55.

Golden Software, Inc. 2002. Surfer 8.0 User's Guide: Contouring and 3D Surface Mapping for Scientist And Engineers Golden Software, Inc., Golden, CO, USA.

Groot Koerkamp P.W.G., Metz J.H.M., Uenk G.H., Phillips V.R., Holden M.R., Sneath M.R., Short J.L., White R.P., Hartung J., Seedorf J., Linkert K.H., Pedersen S., Takai H., Johnsen J.O., Wathes C.M. 1998. Concentrations and emissions of ammonia in livestock buildings in Northern Europe. J. Agr. Eng. Res. 70:79-95.

Hol J.M.G., Scheer A., Ogink N.W.M. 2004. Onderzoek naar de ammoniak- en geuremissie van stallen LX, Stall voor vodsters en vleeskonijnen. Agrotechnology \& Food Innovations B.V., Report n. 219, Wageninger UR, The Netherlands.

Krupa S.V. 2003. Effects of atmospheric ammonia $\left(\mathrm{NH}_{3}\right)$ on terrestrial vegetation: a review. Environ. Pollut. 124:179-221.

Lefcourt A.M. 2002. Some potential problems for measuring ammonia emissions from farm structures. Trans. ASABE. 45:1585-612.

Maertens L., Cavini C., Petracci M. 2005. Nitrogen and phosphorus excretion on commercial rabbit farms: calculations based on the input-output balance. World Rabbit Sci. 13:3-16.

NIOSH (National Institute for Occupational Safety and Health). 2007. Pocket guide to chemical hazards. Publication n. 2005/149, $3^{\text {rd }}$ ed. Department of Health and Human Services, Centers for Disease Control and Prevention, Atlanta, GA, USA. 